\title{
RESPONSE OF LAYING HENS TO DIETARY FULL-FAT \\ SOYBEANS STEAMED FOR DIFFERENT TIME PERIODS
}

\author{
J. O. ATTEH, O. ADEYEMI and K. OKE \\ Department of Animal Production University of Ilorin, Ilorin. \\ (Received 9.July, 1990; accepted 3 October, 1990)
}

\begin{abstract}
Laying hens ( 56 weeks old) were fed for 8 weeks on diets containing $15.5 \%$ of full-fat soybeans steamed for $0,5,10,15$ or 20 minute. Average feed intake and egg production increased, with increase in length of time of steaming. Feed per dozen eggs decreased with increase in time of steaming dietary full-fat soybeans $(P<0.05)$. However, there was no significant effect of the dietary treatments on egg weight. Increasing the time of steaming dietary soybeans improved the retention of both protein and fat. It is concluded that steaming of soybeans did alleviate the problems associated with the feeding of raw soybeans.
\end{abstract}

Keywords: full-fat soybeans, timed steaming, laying hens

\section{INTRODUCTION}

There is increasing interest in the use of fullfat soybeans in poultry diets. This is to take advantage of the high protein and energy content of full-fat soybeans as opposed to the high protein, low energy found in soybean meal. Be. cause of the presence of antinutritional factors (particularly trypsin inhibitor) in raw soybeans, effective use of full-fat soybeans in chicken diets depends on heat treatment (Hill and Renner 1963; Rogler and Carrick 1964; Moran et al., 1973). Existing methods for heating soybeans include autoclaving, micronizing, toasting and extrusion. Most of the current interest in the use of full-fat soybeans are generated by livestock producers who grow soybeans and want to use their on-farm product as an ingredient in livestock feed. Most of the heating method listed above involve the use of advanced technologies not usually available on the farm and certainly not in developing countries. There is hence the need for the development of simple, practical methods of heating soybeans which are adaptable to the on-farm situation. The present study was designed to observe the response of laying hens to diet treatments with the addition of soybeans steamed by a simple method for different time periods.

Nigerian Journal of Animal Production 17 (1990)

\section{MATERIALS AND METHODS}

Forty Hubbard hens of a commercial strain (56 weeks old) were used for this study. They were individually caged in an open sided house and fed the experimental diets shown in Table 1. The five experimental diets which were isonitrogenous $(17 \% \mathrm{CP})$ and isoenergetic $(11.3$ $\mathrm{MJME} / \mathrm{kg}$ ) contained soybeans steamed for 0,5 , 10,15 or 20 minutes. Steaming was undertaken in a double walled aluminium container using saw dust or firewood as the source of heat. Water at the base of the steaming device was allowed to boil, producing a temperature which usually stabilized at about $110^{\circ} \mathrm{C}$ in the tightly covered steaming chamber. A wire mesh basket containing the soybeans to be steamed was then placed in the steaming chamber, the container tightly covered and initiated. Although the steaming chamber had a capacity for $30 \mathrm{~kg}, 15 \mathrm{~kg}$ of soybeans were steamed at a time. At the end of the steaming period, the soybeans were removed and sun-dried prior to grinding and incorporation into the diets at $15.5 \%$ inclusion level.

Eight laying hens were randomly assigned to each diet. They were individually fed, thus each bird served as a replicate. Both the experimental diets and water were supplied ad libitum and natural day length was approximately $12 \mathrm{~h}$ during the 8-week trial period. Birds were weighed at the beginning and end of the trial, and egg production was recorded throughout the trial. Feed consumption was measured on a weekly basis, while eggs were collected three times a week for weighing.

A nutrient retention sturdy was undertaken with the same birds during the 4th week of the trial. Weighed quantities of feed were suppled and excreta samples were dried in a forced air oven at $70^{\circ} \mathrm{C}$ and ground prior to chemical analysis. NItrogen in both feed and excreta samples was determined by the Kjeldahl procedure (A.O.A.C., 1980), while fat was determined by petroleum ether $\left(\mathrm{Pb} 40-60^{\circ} \mathrm{C}\right)$ extraction in a Soxhlet apparatus. 
TABLE 1. INGREDIENT AND COMPOSITION OF EXPERIMENTAL DIETS $(\mathrm{g} / \mathrm{kg})^{1}$

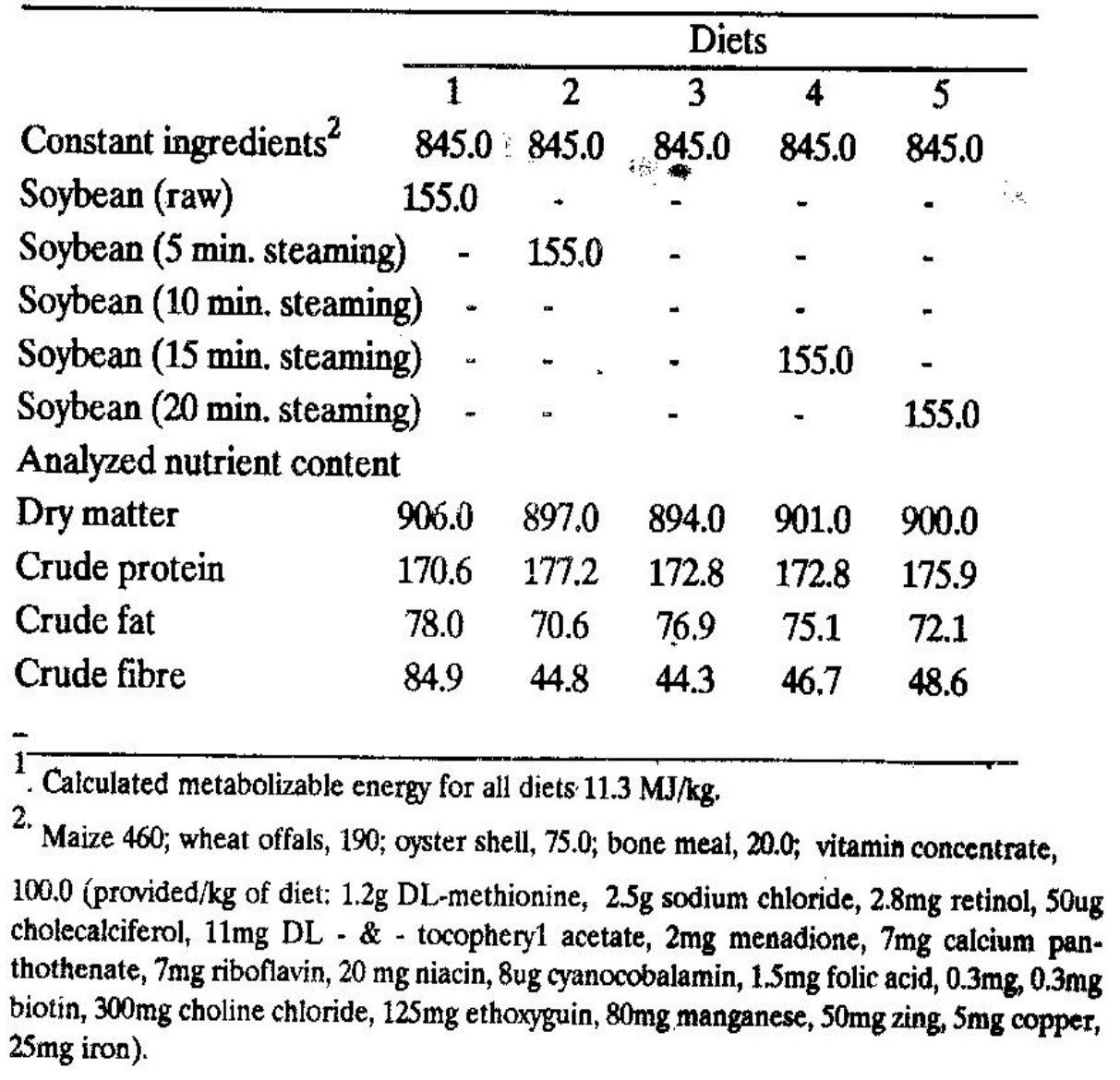

Dois collected was subjected to a one way and 3 is variance, using the completely randomized design (Steel and Torrie, 1980). Means of response variables having a significant F-test were further subjected to Duncan's multiple range test (Duncan, 1955).

\section{RESULTS}

\section{Layer Performance}

Table 2. shows the influence of dietary full-fat soybeans steamed for different time periods on bird performance. There was an increase in average daily feed intake and egg production with increase in the period of time of steaming $(\mathrm{P}<.05)$. Although all the birds used lost weight during the trial, weight loss by birds was inversely proportional to the length of time that the dietary soybeans xere heat treated $(\mathrm{P}<.05)$. There was also a decrease in feed required per dozen eggs produced with increased time of steaming the dietary soybeans $(\mathrm{P}<<255.05)$. However, there was no significant effect of the soybean treatment on egg weight $(P>.05)$.

\section{Nutrient Retention}

Although there was an improvement in the retention of both protein and fat, with increased time of steaming soybeans, these effects were not statistically significant $(P>.05, T \alpha \beta \lambda \varepsilon 3)$.

\section{DISCUSSION}

Fisher et al., (1957); and Saxena et al. (1963) reported that laying hens were insensitive to growth inhibiting properties of raw soybeans. The performance of birds fed the diet with raw soybeans in this study showed that dietary raw soybeans were detrimental to the perfornance of laying hens as indicated by the low feed intake, weight loss and low egg production. The present results seem to confirm earlier reports (Bornstein and Lipstein, 1963, Rogler and Carrick 1964; Moran et al., 1973) showing the negative effects of raw dietary full-fat soybeans on performance of chickens. 
TABLE 2. EFFECTS OF TIME OF STEAMING DIETARY FULL FAT SOYBEANS ON PERFORMANCE OP LAYING HENS OVER AND 8 - WEEX PERIOD

\begin{tabular}{lccccc}
\hline & $\begin{array}{c}\text { Daily Feed } \\
\text { intake } \\
(\mathrm{g} / \mathrm{hen})\end{array}$ & $\begin{array}{c}\text { Body weight } \\
\text { gaiin } \\
(\mathrm{g} / \mathrm{hen} / \text { day }) \\
*\end{array}$ & $\begin{array}{c}\text { Hen Day } \\
\text { Production } \\
(\%)\end{array}$ & $\begin{array}{c}\text { Feed per } \\
\text { dozen eggs } \\
(\mathrm{kg})\end{array}$ & $\begin{array}{c}\text { Mean egg } \\
\text { weight } \\
(\mathrm{g})\end{array}$ \\
\hline soybeans (min) & $*$ & $-4.2 \mathrm{~b}$ & $32.1 \mathrm{a}$ & $3.91 \mathrm{~b}$ & 57.5 \\
\hline 0 & $85.3 \mathrm{a}$ & $-3.4 \mathrm{ab}$ & $40.4 \mathrm{ab}$ & $2.79 \mathrm{a}$ & 58.7 \\
5 & $91.6 \mathrm{~b}$ & $-3.3 \mathrm{ab}$ & $46.4 \mathrm{bc}$ & $2.38 \mathrm{a}$ & 57.2 \\
10 & $90.3 \mathrm{ab}$ & $-2.7 \mathrm{ab}$ & $50.9 \mathrm{c}$ & $2.35 \mathrm{a}$ & 57.3 \\
15 & $96.4 \mathrm{bc}$ & 0.67 & 5.35 & 0.29 & 0.49 \\
\hline S.E.M. & 3.43 & &
\end{tabular}

Means within column followed by different letters are significantly different $(P<0.05)$.

Heat treatment is known to destroy the trypsin inhibitor present in raw soybeans (Mustakas et al., 1946; Kouzeh-Hanani et al., 1981; Beckric et al., 1987). The present study showed that "steaming" of dietary soybeans did alleviate the problems associated with feeding raw soybeans. This is an indication that steaming is effective in destroying the anti-nutritional factors in raw soybeans. Thus feed intake, egg production, feed/dozen eggs and protein retention were improved with steaming of dietary soybeans. On the average, all the birds used in this trial lost weight during the trial, suggesting that egg production was accomplished to some extent at the expense of body reserves.

The effectiveness of steaming soybeans was directly related to the length of time for which the soybeans were exposed to the steam. Thus, feed intake and egg production were increased, and the feed was more efficiently utilized with increase in length of steaming from 0 to 2 minutes.

TABLE 3. EFFECTS OF TIME OF STEAMING DIETARY FULL-FAT SOYBEANS ON PROTEIN AND FAT RETENTION BY LAYING HENS (\%)

\begin{tabular}{|c|c|c|}
\hline & \multicolumn{2}{|c|}{ Protein Fat } \\
\hline Time of steaming (min) & NS & NS \\
\hline 0 & 38.3 & 67.88 \\
\hline 5 & 41.8 & 68.05 \\
\hline 10 & 45.8 & 65.2 \\
\hline 15 & 52.6 & 76.64 \\
\hline 20 & 50.2 & 75.63 \\
\hline SEM & 2.58 & 3.00 \\
\hline
\end{tabular}

NS No significant difference $(P>0.05)$.
The degree of body weight loss was reduced with incresed time of steaming dietary soybeans. The result of the present study did not allow a statement on the optimum steaming time for soybeans. Further studies would be necessary in order to determine an additional advantage of heating soybeans beyond 20 minutes.

\section{ACKNOWLEDGEMENTS}

This work was supported by a grant from the University of Ilorin Senate Research Committee. We also thank the Kwara State Agricultural Development Corporation, Ilorin, for the use of their facilities.

\section{REFERENCES}

ASSOCIATION OF OFFICIAL ANALYTI CAL CHEMISTS 1980. Official Methods of nalysis 13th edn., pp. 127. Association of Official Analytical Chemists, Washington, D. C.

BEKTIC, V., BOZOVIC, I. \& POLIC, D. 1987. Technology of heating feed grains involving communition and its potential application in the feed industry. Krmiva 29: $101-110$.

BORNSTEIN, S. \& LIPSTEIN, B. 1963. The influence of age of chicks on their sensitivity to raw soybean oil meal. Poultry Science 42: 61 70 .

DUNCAN, D. R. 1955. Multiple range and multiple F tests. Biometrics 11: 1 - 42.

FISHER, H, JOHNSON, D. \& FERDO, S. 1957. The utilization of raw soybean meal protein for egg production in the chicken. Joumal of Nutrition 60: 611 - 621 . 
HILL, F. W. \& FRENNER, R. 1963. Effects of heat treatment on the metabolizable energy value of soybeans and extracted soybean flakes for the hen. Joumal of Nutrition 80: 375 -380 .

KOUZEH/HANANI, M., VANZUILICHEM, D. J., ROOZEN, J. P. \& PILNIK, W. 1981. A modified procedure for low temperature infrared radiation of soybeans. part I. Improvement of nutritive quality of full-fat flour. Lebensm Wiss U-Technology, 14: 242 - 244.

MORAN, E. T., SOMERS, J. \& LARMOND, E. 1973. Full-fat soybeans for growing and finishing large white turkeys. 1. Live performance and carcass quality. Poultry Science 52: 1936 - 1941.
MUSTAKAS, G. C., GRIFFIN, E. L., ALLEN, L. E. \& SMITH, O. B. 1964. Production and nutritional evaluation of extrusion - cooked full-fat soybean flour. Joumal of the American Oil Chemist's Society 41: 607 - 614.

ROGLER, J. C. \& CARRICK, C. W. 1964. Studies on raw and heated unextracted soybeans for layers. Poultry Science 43: 605 612.

SAXENA, H.C., JENSEN, L.S. \& MCGINNIS, J. 1963. Influence of age on utilization of raw soybean meal by chickens. Joumal of Nutrition, 80: 391 - 396.

STEEL, R. G. D. \& TORRIE, J. H. 1980. Principles and Procedures of Statistics. A Biometrical Approach. 2nd edn. McGraw-Hill New York. 